\title{
RETRACTION: Resource-Saving in Food Production: Features, Principles, Perspectives
}

\author{
Bogomolova I.P.* \\ Department of Production and Branch Economy \\ Organization Management, Voronezh State University \\ of Engineering Technologies, \\ Voronezh, Russia \\ e-mail: uopioe@yandex.ru \\ Krivenko E.I. \\ Department of Production and Branch Economy \\ Organization Management, Voronezh State University \\ of Engineering Technologies, \\ Voronezh, Russia \\ e-mail: e.krivenko@bk.ru \\ Vorontsova Yu. N. \\ Department of Production and Branch Economy \\ Organization Management, Voronezh State University \\ of Engineering Technologies, \\ Voronezh, Russia \\ e-mail: voronzowa904214@yandex.ru
}

\author{
Stryapchikh E.S. \\ Department of Production and Branch Economy \\ Organization Management, Voronezh State University \\ of Engineering Technologies, \\ Voronezh, Russia \\ e-mail: elena_stryapchih@mail.ru \\ Chernikov V.V. \\ Department of Production and Branch Economy \\ Organization Management, Voronezh State University \\ of Engineering Technologies, \\ Voronezh, Russia \\ e-mail: chernikoff13@yandex.ru \\ Frolova V. P. \\ Department of Production and Branch Economy \\ Organization Management, Voronezh State University \\ of Engineering Technologies, \\ Voronezh, Russia \\ e-mail: verairafrolova@mail.ru
}

This article has been retracted: please see the Atlantis Press Policy on Article Retraction and Withdrawal ("https://www.atlantis-press.com/policies/article-retraction-and-withdrawal").

The Editors and Publisher would like to report that this article is an accidental duplication of an article that has already been published in Advances in Economics, Business and Management Research, Atlantis Press, Vol. 148, August 2020 ("https://doi.org/10.2991/aebmr.k.200730.062"). The duplicate article has therefore been retracted.

All parties would like to apologize for this administrative error 